\title{
QANE AFI

\section{Interview with the 2013 Recipient of the Dr. Pat Griffin Research Scholar Award / Entrevue avec la récipiendaire 2013 du prix du leader scientifique « Dr. Pat Griffin » de I'ACÉSI}

Florence Myrick

amyrick@ualberta.ca

Jacinthe I. Pepin

Université de Montréal, jacinthe.pepin@umontreal.ca

Follow this and additional works at: https://qane-afı.casn.ca/journal

\section{Recommended Citation}

Myrick, Florence and Pepin, Jacinthe I. (2014) "Interview with the 2013 Recipient of the Dr. Pat Griffin Research Scholar Award / Entrevue avec la récipiendaire 2013 du prix du leader scientifique « Dr. Pat Griffin » de l'ACÉSI," Quality Advancement in Nursing Education - Avancées en formation infirmière: Vol. 1: Iss. 1, Article 7.

DOI: https://doi.org/10.17483/2368-6669.1022

This Interview is brought to you for free and open access by Quality Advancement in Nursing Education - Avancées en formation infirmière. It has been accepted for inclusion in Quality Advancement in Nursing Education - Avancées en formation infirmière by an authorized editor of Quality Advancement in Nursing Education - Avancées en formation infirmière. 
The Dr. Pat Griffin Research Scholar Award is presented annually to an established Canadian scholar with a strong program of research in nursing education. The purpose of this award is to support and promote nursing education research through inquiry, mentorship, and dissemination.

Interview with the 2013 Recipient of the Dr. Pat Griffin Research Scholar Award

Interviewer: Dr. Florence Myrick, Co-editor in Chief

Interviewee: Dr. Joanne Profetto-McGrath, Prof. and Vice-Dean, FON, U. of Alberta

Dr. Myrick: What has receiving this award meant to you in your program of research?

Dr. Profetto-McGrath: It has actually meant a great deal to me. First of all, I was honored even to be nominated by my colleagues at the Faculty of Nursing. And, of course, I knew Pat Griffin for a number of years. She was so committed to advancing nursing education, so for me to receive this award as someone who has had a major commitment to nursing education over the decades, and someone who loves teaching and wants to always improve what we do in nursing education and in our lives as educators - it has meant a great deal. As you also know and appreciate, funding for nursing education research is very limited. So to be awarded this scholar award, which also entails a monetary component - it has really meant a great deal to me.

Dr. Myrick: How has the funding you have received through this award allowed you to extend your program of research?

Dr. Profetto-McGrath: One of my areas of passion, interest and research has been critical thinking. The research project that this award has allowed me to support fits with that program of research with regard to examining
Le prix du leader scientifique Dr. Pat Griffin de l'ACÉSI est présentée chaque année à un ou une chercheur(e) canadien(ne) reconnu(e) dans le domaine de la formation en sciences infirmières et dont le programme de recherche est bien établi. Le but de ce prix de leader scientifique est de soutenir et promouvoir la recherche sur la formation en sciences infirmières, via le développement et la diffusion de connaissances de même que le mentorat.

Entrevue avec la récipiendaire 2013 de le prix du leader scientifique «Dr. Pat Griffin » de l'ACÉSI

Intervieweuse: Dr. Florence Myrick, Coéditrice-en-chef

Interviewée: Dr. Joanne Profetto-McGrath, Prof. et vice-doyenne, FSI, U. of Alberta

Dr. Myrick: Qu'est-ce que le fait de recevoir ce prix de leader scientifique signifie pour vous au regard de votre programme de recherche?

Dr. Profetto-McGrath: Cela signifie beaucoup pour moi. D'abord, j'ai été honorée d'avoir été proposée par mes collègues de la Faculté des sciences infirmières. Et, bien sûr, j'ai connu Dr. Pat Griffin pendant plusieurs années. Je savais qu'elle était très engagée envers l'avancement de la qualité de la formation infirmière. Alors, recevoir ce prix pour mon solide engagement envers la formation infirmière au cours de la dernière décennie et parce que j'aime enseigner et que je veux toujours améliorer ce que nous faisons auprès de nos étudiants et dans nos vies comme éducateurs - cela a une grande signification. Comme vous le savez, les fonds pour la recherche sur la formation infirmière sont très limités. Alors, recevoir ce prix, qui comporte un soutien financier, signifie vraiment beaucoup pour moi. 
how can we enhance and further facilitate the development of critical thinking in undergraduate students through the development of teachers in that program.

Dr. Myrick: With regard to your program of research in nursing education, can you discuss some of the strategies you have used over the years to disseminate and implement your findings.

Dr. Profetto-McGrath: I have disseminated my work through the traditional types of strategies - publications, conference presentations, both oral and posters. But in addition to these traditional types of dissemination activities, I have held workshops with nurse educators. For example, some of my research around questioning revealed that as educators we were still really focused only on those types of questions related primarily to the student's knowledge retrieval. We were not using questions focused on developing critical thinkers in our students or those questions related to synthesis, reflection and so forth. Consequently, I have held a number of workshops with nurse educators who were interested in learning more about ways to structure questions, for example, when giving a lecture in a large classroom. Moreover, how do you incorporate well developed questions that stimulate the critical thinking of students collectively? Consequently, I have conducted numerous workshops and they have been really well received. I have been asked to repeat for those individuals who had not had the opportunity to attend the previous workshops. So I have certainly done that.

Also, some of the classes I have taught with undergraduate students have been related to critical thinking and evidence based practice. In these classes I discuss and provide students with examples specifically related to nursing education research. For example, I discuss the questioning process, research and findings. I
Dr. Myrick: Comment le soutien financier que vous avez reçu grâce à ce prix a t'il facilité la poursuite de votre programme de recherche?

Dr. Profetto-McGrath: La pensée critique est un des champs d'intérêt de recherche qui me passionnent. Le projet de recherche que ce prix m'a permis de réaliser s'inscrit dans mon programme de recherche visant à examiner comment renforcer et soutenir encore davantage le développement de la pensée critique chez les étudiants du premier cycle universitaire; dans le cas de ce projet par la formation de formateurs.

Dr. Myrick: Pouvez-vous parler de stratégies que vous avez utilisées pour diffuser et implanter vos résultats tout au long de votre programme de recherche sur la formation infirmière.

Dr. Profetto-McGrath: J'ai diffusé mes travaux via les stratégies habituelles, soit des publications et des présentations lors de conférences, présentations orales ou par affiches. En plus de ces stratégies traditionnelles, j'ai animé des ateliers avec des infirmières formatrices. Par exemple, mes travaux de recherche sur la façon de poser des questions m'ont informée que, comme enseignantes, nous étions encore très centrées sur des questions qui visent principalement le bagage de connaissances des étudiants et étudiantes. Nous n'utilisions pas suffisamment de questions qui visent le développement de ces étudiants comme penseurs critiques, ni de questions qui font appel à la synthèse, à la réflexion ou à d'autres processus. Donc, j'ai mené des ateliers pour les infirmières enseignantes intéressées à apprendre comment formuler des questions, par exemple dans le cadre d'un cours magistral donné à une grande classe. Aussi, comment utiliser des questions bien formulées qui stimulent la 
talk about their preceptorship experiences. I discuss how we structure preceptorship and the work we do to prepare them and their preceptors. I also discuss how it is based on the evidence that has been accumulated over the years by scholars such as Yonge, Myrick, Jackman and others. Through such discussions the students can come to understand that what we are teaching and the strategies we are actually using, are based on research evidence as well as our experience as educators. That has been one other way that I have disseminated my research findings.

Also, with the graduate students I have supervised over the years, particularly those who were focusing on nursing education, I have discussed as supervisor/teacher/mentor, the evidence base of nursing education. This process has both propelled their work forward and generated their excitement about research. In fact, some of the work they have completed, or were in the process of completing at the time, has the potential to contribute to building evidence based knowledge for nursing education. These are some of the key ways that I have disseminated the research findings with the hope that such knowledge would be taken up and used in their day to day work and in which they may engage as future researchers as well.

Dr. Myrick: In addition, I would like to point out, for our readers, that you are well published in journals for nursing education as well.

Dr. Profetto-McGrath: Yes, that certainly has been a priority for me - to ensure that the research in which I have engaged has been published so others may avail of it. Occasionally, when I check on citations related to my work they are really strong, not only nationally but internationally. So it really makes me proud to know that my work is being used to support the work and research of others both nationally and internationally. pensée critique d'étudiants en tant que groupe? Les ateliers que j'ai donnés ont été très bien accueillis; on m'a demandé de les répéter pour des personnes qui ne pouvaient participer la première fois, ce que j'ai fait.

Aussi, j'ai enseigné certains cours au premier cycle en lien avec la pensée critique et la pratique fondée sur des résultats probants. Dans ces cours, je discute avec les étudiants et leur donne des exemples liés à la recherche sur la formation en sciences infirmières. Par exemple, je leur parle de ma recherche et des résultats sur le processus de poser des questions et sur le préceptorat. Je discute de la structure du préceptorat et du travail que nous faisons pour préparer les étudiants et les précepteurs à cette expérience. Je présente comment ces travaux sont fondés sur des résultats accumulés au fil des années par de nombreux chercheurs chevronnés dont Yonge, Myrick, Jackman et autres. Ces échanges amènent les étudiants à comprendre que ce que nous enseignons et les stratégies d'enseignement que nous utilisons sont fondés sur des résultats probants autant que sur notre expérience comme enseignants. C'est un autre moyen de diffuser les résultats de mes recherches.

De plus, j'ai échangé sur les fondements théoriques et scientifiques de la formation infirmière avec les étudiants des cycles supérieurs que j'ai supervisés au fil des années, ou encore comme professeure ou mentor. Ces échanges ont suscité leur enthousiasme face à la recherche et ont propulsé leurs travaux. Certains ont complété ou sont sur le point de terminer des projets qui ont vraiment le potentiel de contribuer aux connaissances actuelles sur la formation infirmière. Voilà, ce sont quelques-unes des stratégies que j'ai utilisées pour la diffusion des résultats de mes recherches dans l'espoir que ces connaissances puissent servir au quotidien 
Dr. Myrick: How would you say the role of research contributes to the quality advancement of nursing education?

Dr. Profetto-McGrath: I think research is critical to the quality advancement of nursing education. We talk a lot about evidence based nursing practice. Nursing education has to be in that same realm. What we do in nursing education, whether it is related to pedagogy, or curriculum development has to be based on the best evidence that we have available. A major component of evidence, at least from my perspective, comes from research. It can certainly come from the experience of educators because that also needs to be honored. Research is achieved through a variety of methodologies including mixed methods, qualitative/quantitative research studies which I think serve to strengthen the science behind what we do in our practice as educators. I think it is crucial. Also, it has that sense of recognition that is not only based on what we have been doing over the years but that we actually challenge it in some ways through research.

Dr. Myrick: Generally, what would you say is the biggest achievement in nursing education?

Dr. Profetto-McGrath: There are probably a number. One that I believe to be at the top of the list, is doctoral education. In Canada, our commitment to doctoral education has been so strong. When you consider the programs that have been established from coast to coast to support nursing education, and from those the number of scholars who have evolved and who are carrying out research and the work related to nursing education, you realize the importance of such programs in developing the knowledge base for our area. So that has been one. Nurse educators at the doctoral level not only carry on research, but also apply it to their teaching, and their mentorship in general. A second important achievement has been the de mes étudiants et susciter chez certains le désir de s'engager comme nouveaux chercheurs.

Dr. Myrick: J'aimerais ajouter que vous avez aussi publié de nombreux articles dans des revues portant sur la formation en sciences infirmières.

Dr. Profetto-McGrath: Oui, cela a certainement été une priorité pour moi dans le but de rendre accessibles les résultats des recherches dans lesquelles j'ai participé. Quand j'ai eu l'occasion de vérifier les citations reliées à mes travaux, j'ai trouvé qu'elles étaient nombreuses, tant sur le plan national qu'international. Cela me rend fière que mes travaux puissent soutenir les recherches d'autres chercheurs.

Dr. Myrick: Pouvez-vous expliquer la contribution de la recherche à l'avancement de la qualité de la formation infirmière?

Dr. Profetto-McGrath: Je pense que la recherche joue un rôle central dans l'avancement de la qualité. On parle beaucoup de pratiques de soins fondées sur des résultats probants. Il doit en être de même pour les pratiques de formation infirmière. Tout ce qu'on fait en formation, que ce soit en lien avec la pédagogie ou le développement de curriculum, doit être fondé sur les meilleures pratiques disponibles et, à mon avis, ces pratiques découlent idéalement de la recherche. Elles peuvent certainement aussi venir de l'expérience des formateurs, une source qu'il nous faut respecter. Les recherches sont menées en utilisant une variété de méthodologies, qualitatives, quantitatives ou mixtes, ce qui permet de renforcer la science qui soutient nos pratiques académiques. C'est crucial. Ainsi, la recherche nous amène à questionner et revoir nos pratiques. 
baccalaureate as the entry-to-practice in Canada, a really key achievement. Nurses are key to the transformation of health care systems. Baccalaureate education provides a solid foundation to do so. It also serves as the basis on which nurses can build their ongoing development including graduate work. As well, there is ample and robust research to support that hospitals with higher proportions of baccalaureate prepared nurses have reported a decrease in patient mortality and improved outcomes. Also, a more educated workforce is needed for primary care, and health promotion.

Dr. Myrick: What do you see as the biggest challenge that is facing nursing education today?

Dr. Profetto-McGrath: There are, I think, a number of challenges we face. A major one is the minimal funding available to support nursing education research - funding to support not only individual research projects but also programs of research and Research Chairs in nursing education. The second challenge is that we still need to strengthen the evidence to support teaching pedagogy, student engagement and a number of other areas related to nursing education.

Dr. Myrick: You are referring here specifically to our nursing education practice.

Dr. Profetto-McGrath: Yes, I believe that we are still using some strategies in our teaching of students in undergraduate and graduate programs that are not fully researched. It probably relates to the belief that we have done things that way for a while and we think it works. Yet, there may be no evidence to support these positions. We, therefore, need to continue to work to educate scholars who are prepared and willing to continue research in the area of nursing education. One more I will mention related to scholarly preparation and funding is moving beyond the descriptive and
Dr. Myrick: Quel est selon vous la plus grande réalisation de la formation en sciences infirmières?

Dr. Profetto-McGrath: Il y en a probablement plus d'une. Au haut de la liste, je crois que je placerais la formation doctorale. Notre engagement au Canada face à la formation doctorale est très solide. Quand on pense aux programmes établis d'un océan à l'autre pour soutenir la formation infirmière et le nombre de chercheurs qui sont sortis de ces programmes et qui mènent des travaux de recherche, certains dans le domaine de la formation infirmière, on réalise l'importance de ces programmes pour le développement de savoirs en sciences infirmières. Les professeurs qui enseignent au troisième cycle, non seulement dirigent des recherches mais utilisent des résultats dans leur enseignement et leur supervision en général.

Une deuxième réalisation importante est la formation au baccalauréat pour l'entrée dans la pratique infirmière au Canada. Les infirmières jouent un rôle clé dans la transformation des systèmes de santé et la formation au baccalauréat leur fournit une base solide sur laquelle construire. $\mathrm{Ce}$ programme les prépare à un développement continu qui peut inclure des études supérieures. En plus, il existe de nombreuses études rigoureuses qui indiquent que les hôpitaux qui ont une proportion plus élevée d'infirmières formées au baccalauréat présentent un taux de mortalité réduit et de meilleurs résultats patients. Enfin, la première ligne qui inclut la promotion de la santé a besoin de professionnels solidement formés.

Dr. Myrick: Quel est selon vous le plus grand défi qui confronte la formation en sciences infirmières aujourd'hui? 
correlational studies - into approaches that can include ethnography, or experimental. For example, the use of ethnography is a way to explore what is happening in the teaching and learning environment that involves students, faculty, health care providers and clients which may not be addressed through the use of descriptive or correlational studies, which are also important.

Dr. Myrick: Can you elaborate?

Dr. Profetto-McGrath: Interestingly, one of my doctoral students, who in fact endeavored to use ethnography as part of her doctoral research found that there was very little appetite on the part of nurse educators to be involved in that particular kind of study. There are probably a number of different reasons they might think that "oh, I'm going to be exposed..." with regard to what it is they do as a nurse educator in the practice setting. They might question whether they are in fact good at what they do. Consequently, the idea of someone actually following them and trying to explore how they approach teaching students in the practice setting within a complex context may be a little bit frightening. We need to really move into that realm of research if we want to extend our understanding.

Dr. Myrick: Are there any other comments you would like to make before we conclude our interview?

Dr. Profetto-McGrath: Well, what I want to do is to put a challenge out there for all of us who are really passionate about nursing education - to do what we can locally, provincially and nationally to advocate for and support nursing education research, any activities that are being carried out at various levels to raise money, to advocate for funding at the national level for nursing education. I know some of us, including you Flo, have tried and met with people at the national level. We
Dr. Profetto-McGrath: Je pense que nous rencontrons un certain nombre de défis. Un des plus importants défis est celui des sources limitées de financement pour la recherche sur la formation infirmière - non seulement pour les projets individuels de recherche mais pour des programmes de recherche et des Chaires de recherche en formation infirmière. Un deuxième défi est la nécessité de renforcer les résultats qui soutiennent l'enseignement de la pédagogie, l'engagement des étudiants et d'autres objets de recherche liés à la formation en sciences infirmières.

Dr. Myrick: Vous vous référez à notre pratique de formation en sciences infirmières.

Dr. Profetto-McGrath: Oui, je crois que nous utilisons encore des stratégies d'enseignement auprès des étudiants de premier cycle et des cycles supérieurs qui n'ont pas été amplement étudiées. Cela est probablement lié à la croyance que nous avons fait les choses d'une certaine manière pendant longtemps et nous pensons qu'elles fonctionnent. Cependant, il se pourrait que la recherche ne puisse pas soutenir notre façon de faire. En conséquence, nous devons continuer à former des chercheurs prêts à s'engager en recherche dans le domaine de la formation infirmière. J'ajouterais, en lien avec la préparation académique et les demandes de subventions, que les approches de recherche pourraient aller au-delà des études descriptives et corrélationnelles, pour inclure, entre autres, l'ethnographie et les études expérimentales. Par exemple, l'ethnographie permettrait d'explorer ce qui se passe dans l'enseignement et l'environnement d'apprentissage, qui inclut les étudiants, les professeurs, les professionnels soignants et les patients; des éléments qui ne pourraient pas faire l'objet d'études descriptives ou corrélationnelles. 
need to be advocates for nursing education research and related aspects, to make that happen, to continue to support the Pat Griffin research fund. Moreover, it is national funding that recognizes scholars in the nursing education field and supports those of us who have been fortunate enough to be the recipients.

Dr. Myrick: On behalf of the Quality Advancement in Nursing Education/ Avancées en formation infirmière Journal I would like to take this opportunity to thank you for taking the time to participate in this interview and to share your knowledge, experience and wisdom as a nurse educator and the current CASN Research Scholar.
Dr. Myrick: Pouvez-vous élaborer?

Dr. Profetto-McGrath: En fait, une de mes étudiantes, qui entreprend sa recherche doctorale à partir d'une ethnographie, a trouvé que peu de formateurs étaient intéressés à participer à ce type d'étude. Il y a probablement plusieurs raisons - ils peuvent penser «oh, je vais être exposé...» concernant ce qu'ils font comme formateurs en milieu de pratique. Ils peuvent se demander si, en fait, ils sont bons dans ce qu'ils font. Ainsi, l'idée qu'une personne les suive et tente de comprendre leur approche auprès d'étudiants en milieu de soins dans contexte complexe, peut inquiéter. Nous devons vraiment penser en termes de recherche si nous voulons approfondir notre compréhension.

Dr. Myrick: Aimeriez-vous ajouter quelque chose avant que nous terminions l'entrevue?

Dr. Profetto-McGrath: Bien, ce que j'aimerais ajouter, c'est de lancer un défi à tous les passionnés de formation infirmière, de faire ce qui nous est possible au plan local, provincial et national pour soutenir la recherche sur la formation infirmière, pour soutenir le financement de la recherche ou pour encourager toute activité visant des levées de fonds ou des prises de position nationale en faveur du financement de la recherche sur la formation infirmière. Je connais des personnes, incluant vous, qui avez fait des démarches auprès de grands organismes nationaux. Nous devons promouvoir la recherche sur la formation infirmière et continuer de soutenir la Fondation de recherche Dr Pat Griffin. Cette Fondation nationale reconnait des leaders scientifiques dans le domaine de la formation infirmière et soutient leurs travaux de recherche. 
Dr. Myrick: $\mathrm{Au}$ nom de Quality Advancement in Nursing Education Journal I Avancées en formation infirmière, j'aimerais profiter de l'occasion pour vous remercier chaleureusement d'avoir pris le temps de participer à cette entrevue et de partager votre connaissance, votre expérience et votre expertise de leader formatrice en sciences infirmières. 